\title{
Turkey's changing security perceptions and expenditures in the 2000s: Substitutes or complements?
}

\section{Gulden Ayman and Gulay Gunluk-Senesen}

Gulden Ayman is Professor of International Relations, Faculty of Political Sciences, Istanbul University, Istanbul, Turkey. She may be reached at guldenayman@gmail.com. Gulay Gunluk-Senesen is Professor of Public Finance, Faculty of Political Sciences, Istanbul University, Istanbul, Turkey. She may be reached at gulaygs@istanbul.edu.tr.

\section{Abstract}

This article explains changes in Turkey's security perceptions after the current ruling party, the AKP, came to power. It focuses on how Turkey tried to change the structure of conflictual relations with countries it has long viewed as sources of threat. Focusing on Syria, especially, the article delineates economic tools for conflict reduction and regional integration employed by Turkey and analyzes the challenges and main obstacles that the Turkish government has faced, especially after the Arab spring upheavals. The article then devotes attention to Turkey's military modernization efforts launched to cope with the new threat environment and from there moves on to elaborate on the effect of security policy preferences and design on Turkish security-related resource allocation since the early 2000s. The intermingled nature of internal and external security policies calls for broadening the context of the economic aspects of security to include police, gendarmerie, and coast guard services along with the military. Descriptive analysis of on-budget components and off-budget facilities shed light on Turkey's recent position in the international arena as an important military spender and arms importer.

$\mathrm{S}$ tates do not treat disagreements over all types of issues the same. In particular, territorial disagreements are much more likely to generate crises that, in turn, can produce high probabilities of escalation to interstate war. Explanations for why territory triggers crises and wars include tangible as well as intangible elements. Among the former are ownership of, or access to, natural resources as well as the desire to access sea lanes or other commercial transport routes or factors related to ethnicity or the religious preferences of populations. Yet, what drives states and peoples willingly to make tremendous sacrifices for territory can ultimately only be understood through intangible elements. Territory has high symbolic value, for example as a historic or religious homeland, and is one reason why it is relatively easy for governments to mobilize domestic support regarding territorial issues. Territorial claims often encourage states to believe in power politics, and this includes military build-ups and the forming of alliances. In contrast to proponents of realism, though, liberal peace scholars often assume that economically interdependent states, connected by foreign direct investment and trade, can promote peace across borders. ${ }^{1}$

The first part of this article addresses the following questions: (1) Under what type of conditions does Turkey appear to choose economic tools of conflict resolution rather than leaning toward military ones? (2) What is the role played by "Turkish identity"? (3) What challenges and obstacles may have impeded the success of Turkish policy when it prioritized the economic means?

Turkey's security perceptions, policies, and postures need to be viewed also in light of its economic capacity. As it turn out, its economic growth has given it the means for greater military expenditure, and yet such spending growth has not occurred. The second part of the article therefore elaborates on Turkish preferences regarding its internal and external security policy design, and their effects on resource allocation, and evaluates security-related on-budget and off-budget data.

\section{The new approach to security concerns}

Although Iran, Iraq, and Armenia were part of Turkey's threat perceptions in the 1990s, Turkey's major concerns then were Greece and Syria. In military terms, Greece was the primary source of anxiety due to unresolved problems concerning the Aegean Sea. The Kardak/Imia crisis of 1996 between Turkey and Greece, for instance, demonstrated how unresolved issues over the Aegean could bring the two countries to the brink of war. The likelihood of war between Turkey and Syria, however, because of the latter's claims to Turkish territory and its support of the Kurdistan Workers' Party (Kurdish: Partiya Karkerên Kurdistanê, or PKK), was not considered high, not only because of the power asymmetry between the two countries but also because Syria toned down its claims (although the area remained on Syrian maps) after the 
Arab-Israeli conflict became a Syrian priority. Nonetheless, Turkish defense planners recommended to prepare for all eventualities. According to ex-Ambassador Sukru Elekdag, the Turkish Armed Forces (TAF) should be prepared to carry out "two-and-a half campaigns," that is, be able to conduct two full-scale operations simultaneously along the Aegean and southern fronts and a "half war" that might be instigated from within the country. ${ }^{2}$

With the rise to power in 2002 of the Justice and Development Party (Turkish: Adalet ve Kalkinma Partisi, or AKP), a party rooted in Turkey's Islamist then-opposition, not only were new social and political approaches introduced, but a new understanding to address Turkey's various security problems was adopted. Anxiety felt by AKP cadres regarding attempts of the secular opposition and the military to curb its new power deeply affected how Turkey's security concerns and the TAF were viewed. AKP circles largely thought that, in the past, external security threats were purposefully exaggerated in order to increase the role of the Turkish army in political life. The AKP believes that it rescued Turkey from such fears and insecurities in a way that would enable it to approach foreign policy and regional affairs from a new, different angle. This line of thought asserted that there then should emerge a consequent structural change in Turkey's relations, concentrating on diplomacy and foreign relations rather than on how to cope with threats originating from its own military. As a proponent of neoliberalism, the AKP leadership relied on the premise of coping with external threats emanating from territorial claims through the development of trade and economic relations with neighboring states. Turkey's growing economic interdependency with the Kurdish Regional Government (KRG) in Iraq played an important role in encouraging the AKP to apply the same understanding to Turkey's relations with other countries. Turkish-Iraqi relations thus underwent a dramatic improvement since 2007 as KRG became more than a simple market for Turkey. As a potential source of natural gas, improved relations with Iraq/KRG were regarded as an asset for Turkey in its attempt to become an energy corridor to Europe. ${ }^{3}$

Terms introduced by the Turkish government to explain its endeavors included a "proactive," "multidimensional," and "rhythmic" diplomacy as opposed to "status quo-oriented," "reactionary," or "defensive" approaches. In this vein, softpower assets of Turkey were highlighted, engagement and economic interdependence emphasized, and mediation roles promoted. These efforts were in sharp contrast to Turkish foreign policy as practiced during most of the 1990s, which was highly securitized and rested upon mostly military means and the balancing of alliances, as in the case of the
The article examines Turkey's changing security perceptions, policies, and postures since the rise of its current ruling party, the AKP, in the early 2000 s and places these in the context of its internal and external security-oriented budget allocations. It finds that in spite of a prolonged period of economic growth, the country's outlays on military expenditures have essentially stalled while allocations to internal security services have risen drastically.

Turkish-Israeli alignment of 1996 against Syria. Thus, Ankara now favored the Annan Plan for achieving a peaceful resolution of the Cyprus conflict, touted the economic benefits of conciliation with Greece as depicted in their growing bilateral trade, and signed two protocols in 2009 with Armenia aimed at normalizing relations. The improvement in Turkish-Syrian relations also manifested itself in trade and economic relations, but beyond that the Turkish government aimed at transforming the border itself to become a "meaningless" entity between the two countries. ${ }^{4}$

Yet, to AKP's disappointment, in the end the Annan Plan failed and Greek-Turkish detente could not be extended to the security field, leaving key differences between the countries unresolved. Furthermore, new concerns, e.g., the decision by the Greek-Cypriot government in 2007 to develop natural gas fields on the southern coast of the island-which it claimed as its own Exclusive Economic Zone-antagonized Turkey and became a litmus test to show whether economic opportunities would bring peaceful solutions or fierce competition and crisis. $^{5}$

Lastly, efforts to normalize the relations initiated by Armenia eventually paused after President Serzh Sarkisian suspended the ratification process because Turkey sought to link ratification of the protocols with progress in a separate dispute between Armenia and Azerbaijan, over the region of Nagorno-Karabakh. Armenia objected to any such conditions and asserted that Ankara should proceed unconditionally. ${ }^{6}$

\section{An imagination beyond borders}

Within the context of a "zero problems with the neighbors" policy, developing good relations with the "Muslim Middle East" became the highest priority of Turkey during the AKP era. Obviously, this shift marked a change from Turkey's traditional foreign policy that looked West more than it looked East or South. What made it unique, however, was the attempt to broaden the definition of self-identity such as to include geography beyond Turkey's official borders. An imagination of a Muslim cemaat (community) was the main motivation of the AKP leadership in its pursuance of an ambitious policy to foster good relations with the region. 
Many academics have pointed out the close relationship between identity and territory. In the field of security, defining identity beyond borders often has resulted in territorial demands in the case of ethnic affiliation or attempts to build a supra-national authority as in the case of the European Union. In the AKP's vision, the alternative to the official abolishment of borders was to transform them into places that would offer an enhanced ability for interaction, exchange, and enrichment. While this endeavor was defended in general as an attempt to realize "Turkey's historic reintegration into its immediate neighborhoods and hence correct an anomaly of the Cold War years," Turks and Arabs in particular were viewed like members of a separated family who were eager to reunite. ${ }^{7}$

Actually, soon after the formation of the cabinet the AKP had to deal with the problem of the United States intending to invade northern Iraq using Turkish territory. Despite efforts by Prime Minister Recep Tayyip Erdogan to pass a bill allowing this, the Turkish parliament rejected it. Ironically, that event catapulted to new heights the popularity of the Turkish government in Arab public opinion.

In the following period, Turkey took important steps to develop and diversify multilateral and bilateral relations with the Arab world. The Turkish Foreign Ministry established consultation mechanisms with a number of Arab countries, including Egypt, Syria, Jordan, Lebanon, Tunisia, Morocco, Libya, Oman, Qatar, and Bahrain. Turkey also made great efforts to increase its stature in the Persian gulf by developing better economic relations with hydrocarbon-rich countries like Kuwait, Qatar, and Bahrain. ${ }^{8}$

While the benefits to be gained from the AKP's endeavor to reintegrate the Middle East were supposedly plenty, the development of economic relations and particularly trade was the most highlighted. Referring to the "trading state" concept of Rosecrance, Kirisci argued that "Turkey has been in the process of becoming a trading state, as foreign trade has steadily grown and come to constitute a growing proportion of its economy." "9

\section{Multi-faceted cooperation with Syria}

Turkey's multi-faceted cooperation efforts constituted the most elaborate example of the kind of tools selected for resolving territorial conflicts and achieving regional reintegration. In 2004, during a visit by Turkish Prime Minister Erdogan, Turkey and Syria signed a free trade agreement and decided to put their differences behind them. The Turkish-Syrian Regional Cooperation Program became operational in 2006, aiming to develop technical, economic, cultural, and scientific cooperation. Its aim was to facilitate regional development by financing projects that would create employment as a priority.
In return, Syrian President al-Assad's visit to Istanbul on 16 September 2009 was pivotal for taking cooperation between the two countries to the strategic level through the establishing of the Syrian-Turkish High-Level Strategic Cooperation Council, and which resulted in signing 51 agreements and opened a new phase in bilateral relations with the decision to lift visa requirements. In January 2010, Turkey and Syria signed a memorandum of understanding outlining their plan to construct a "friendship dam" on the Orontes River, long planned but never realized because of the Hatay question. ${ }^{10} \mathrm{On}$ 10 June 2010, the foreign ministers of Turkey, Syria, Jordan, and Lebanon agreed to set up a "high-level quartet cooperation council" and within this framework decided to establish a free trade zone and a visa-free travel regime among its nationals. The absence of objections by Syria to the establishment of a center in Iskandarunah was regarded as indirect recognition of Turkish sovereignty over the area. Moreover, Turkey and Syria decided to jointly operate border gate facilities in accordance with the Protocol of Cooperation on Procedures on the Movement of Passengers and Goods signed in Lattakia in October 2010 during the 2nd Ministerial Meeting of the Syrian-Turkish High-Level Strategic Cooperation Council. The shared border process first started in Nusaybin, a district in the province of Mardin, which is one of the border areas once riddled with land mines. ${ }^{11}$

\section{Security concerns regain priority}

Reminiscent of steps taken in Europe in the post-second world war era, which laid the foundations of today's European Union, Turkey's regional integration efforts, as demonstrated in the Syrian example, involved a growing number of high-level visits and cooperation pacts on a variety of issues ranging from culture to security. What was missing from the AKP's vision, however, was accounting for the internal vulnerability of the oppressive regimes Turkey contracted with. Thus, lifting visa obligations, facilitating the flow of people across borders, and expanding communication constituted important parts of Turkish policy up until the Arab upheavals in spring 2011.

Initially, the high level of self-confidence related to the apparent success of the "Turkish model," led the AKP to believe that if the Turkish experience was inspiring, Ankara would be the leading source for the new regimes established after the fall of authoritarian rulers. Besides, according to the principle suggested by Davutoglu "if Turkey will be affected in the next stage, it will lead the process today," no matter whether it means intervening in domestic affairs. ${ }^{12}$

In this regard, the election of Muhammad Morsi in Egypt and a like-minded conservative government in Tunisia were considered steps toward a new order in the region. In fact, 
Turkey was reading regional developments through the lens of its own experience and empathizing with them. Even after a coup toppled President Morsi in Egypt, AKP officials argued that the deposed president's popularity would result in his return to power. This argument was underpinned by the steadfast belief that all of the region's dictatorial regimes were either doomed to fail or be overthrown by "the people," who will then elect a "man of the people." Yet experience showed that the fall of an authoritarian regime does not guarantee that democracy will prevail: An unruly civil war might ensue, as in Libya, or authoritarian rule could stay on much longer than expected, as illustrated by the Syrian case. The developments in Libya, Egypt, and Syria resulted in huge economic losses for Turkey. Yet it was the Syrian conflict that posed the most serious threats and risks to Turkey's security.

\section{Syria as a source of threats}

As all the steps taken to make the Turkish-Syrian border "meaningless" proved, Ankara had high expectations of its improved relations with Syria. But when it became clear that it was impossible to convince the latter's leadership to realize reforms, the AKP leadership took a strong stance against the Assad regime. Remarks by President Erdogan point out how identity perceptions shaped Turkey's approach: "We do not see Syria as a foreign problem, Syria is our domestic problem because we have an 850 kilometer border with this country, we have historical and cultural ties, we have kinship." The lesson learned from the Libyan case also was very influential in determining the course of Turkey's actions. Accordingly, if Turkey would leave the determination of Syria's future to extra-regional powers, it could be left out of any deal and might find itself facing a number of risks and threats. Turkey soon became the main staging ground for the Syrian opposition in exile. Yet Turkey's effort to unite and strengthen the opposition forces under a common umbrella favorable to Turkey was not an easy task. ${ }^{13}$

When peaceful rallies escalated into violent conflict and gradually transformed into Syria's civil war, Turkey came to host over 2 million refugees. Adopting an open-door policy came at a high price. As of September 2015, Turkey spent USD7.6 billion on Syrian refugees while international assistance fell strikingly short at USD418 million. The estimated monthly cost of sustaining 25 camps is over USD2 million. The refugee flow strained Turkey's relations especially with Greece. While Turkish authorities asserted that "Turkey has been left alone with this crisis," Greek authorities accused Turkey of aggravating the refugee crisis as a result of the high number of refugees crossing the Aegean Sea. ${ }^{14}$

The war in Syria and the risks and threats it posed for
Turkey resulted in a new approach to border security. To reduce illegal border crossings, Turkey decided to build a two-fenced border system, including roads passing through two-section, wire-mesh fences with observation towers. The government has already renewed $145 \mathrm{~km}$ of wire fence and has set up $90 \mathrm{~km}$ of new fences on the border. A total of $450 \mathrm{~km}$ in other parts of Turkey's border with Syria are to be protected by a new moat. The cost of these measures, including drones, thermal cameras, and motion sensors, will be around 4.2 billion Turkish liras (see the section on the financials later on in this article). Half the personnel of the renewed effort to reinforce border security have been assigned to the Syrian border. ${ }^{15}$

\section{The ongoing civil war in Syria}

By embracing the opposition and severing its ties with the regime in Syria, Turkey sought to achieve two goals: To overthrow Syria's regime and to convince Syrian Kurds to join the armed opposition struggle there. Neither Turkish calls for the establishment of a security buffer zone-which is to serve as a refuge for displaced Syrians, a base for the opposition, and as a cover for air strikes to cripple Syria's air force-nor its search to attract international support for military intervention received positive responses from the West. Moreover, the war against Islamic State of Iraq and Syria (ISIS) benefitted Kurds in establishing an autonomous body with its own military, security, administrative, and economic institutions. Kurdish attempts to impose a fait accompli on the ground caused great anxiety, with Turkish concerns focusing on the possibility of Kurdish expansion and linking to other areas in the far northwest and the possibility of accessing the Mediterranean. These developments raised Turkish fears that Kurds' ultimate goal is the establishment of an independent state in the region. The disillusionment with the West, particularly the United States, led the AKP to argue that "the West is trying to create a second Sykes-Picot out of fragmented and failed states to foster its own rule over the region."16

Russia's direct involvement in Syria further complicated the problem. Turkish-Russian relations became strained after the Turkish Air Force downed a Russian fighter jet in November 2015. Immediately thereafter, Moscow started to support Syrian Kurdish fighters, considered by Turkey to be "terrorists." The economic implications of the crisis were also worrying. Yet Turkey's most important concern regarding Russia is not the possible economic losses or problems that could arise as a result of its dependence on Russian gas, but rather the future of Syria itself, the most critical element of disagreement between Russia and Turkey today.

Turkey's relations with Iran also became strained as a result of the war in Syria. The decision to allow NATO to deploy a 
radar as part of its antimissile system came at a time when Turkey and Iran took different approaches toward Syria. For Iran, the fall of the Assad regime would be considered a threat to its vital interests, while Turkey does not seem to give up its regime-change approach toward Syria. Since the foundation of the Islamic Republic, Syria has been considered Iran's closest state ally. Importantly, the latter provides the crucial link between Iran and Lebanese Hezbollah, acting as a hub to transport personnel, weapons, and finances. Despite the new beginnings sought by the United States, Iran still feels the need of ensuring its own security, systematically trying to increase its strategic depth in Iraq and in Syria.

\section{Perceived threats and risks}

According to Turkish security sources, the developments in the Middle East and North Africa no longer support positive expectations regarding security and stability in the region. The deteriorating situation in Syria and Iraq, and the activities of the Democratic Unity Party (Kurdish: Partiya Yekîtiya Demokrat, an offshoot of the PKK) and of ISIS in these countries and on Turkish territory, are high on the list of perceived threats. ${ }^{17}$

\section{Modernization efforts}

According to Turkish Chief of General Staff, Hulusi Akar, the current and anticipated future conflicts are of a hybrid character, comprising conventional and nonconventional threats. With the increasing complexity of its dimensions and actors, the security and war situation has become difficult to predict, leading Turkey's military to adopt a "security concept" rather than a "defense one." Thus, Turkish military strategy calls for highly adaptive, flexible, resistant, and agile forces, capable of taking quick decisions with a high level of combat preparedness. The task of Turkish military forces, as laid out in Article 35 of the Internal Service Code, shows that the front line could lie beyond Turkey's borders. ${ }^{18}$

The assertive vision and discourse developed by Turkey in recent years and the deteriorated threat environment necessitated an increase in its operational military capabilities. The 2012-2016 Strategic Plan announced by the Turkish Undersecretariat for Defense Industries demonstrates the priorities with regard to military modernization. One of the most striking features of force modernization efforts involves building a domestic missile defense capability. Indeed, the same Turkey that needed NATO's missile defense capabilities against Saddam Hussein's ballistic missiles and weapons of mass destruction during the first Persian gulf war was forced to again request NATO missile defense capabilities on its territories because of the civil war in Syria and Syria's strategic weapon capabilities. Moreover, the Dutch decision to withdraw Patriot antimissile systems urged Turkey to develop its own systems rather than to rely on NATO in crisis situations. ${ }^{19}$

Ankara took three steps to fortify its defense against strategic weapon systems. First, its air force concept changed to include missile defense. Second, the Undersecretariat for Defense Industries launched a Regional Long Range Air and Missile Defense System. Third, an Air and Missile Defense Combat Command was formed within the air force, and an Air Defense Command was created in Eskisehir, which is responsible for the administration of missile defense.

Greece, long the focus of Turkey's military strategic calculations, does not possess land-to-land ballistic missile capabilities nor weapons of mass destruction warheads, only ATACMS tactical ballistic missiles. However, as of 2013, Russia has started to deploy on Armenian territory SS-26 Alexander missiles with a range of $400 \mathrm{~km}$ and capable of carrying warheads of payloads between $480-700 \mathrm{~kg}$. With modifications, these missiles could carry nuclear warheads. Most importantly, they are designed to mislead ballistic missile defense systems. In addition, allegations regarding Russia's violation of the Intermediate Nuclear Forces Treaty (INF) also cause Turkish discomfort. If true, and if the missiles were to remain in Armenia, Turkish cities like Diyarbakir and Malatya that are important military and administrative regions and are the headquarters of the 3rd Army, would lie within the range of those missiles. ${ }^{20}$

In all this, undoubtedly, economic growth is the key enabler of Turkey's modernization efforts. While territorial problems and regional challenges create a desire for military modernization, military power as a source of status is also a motivating factor. In this respect, at least, Turkey displays characteristics similar to other regional powers such as Brazil, India, and South Africa, all with generally growing economies, and of all which play key economic and political roles in their respective regions and engage in significant military modernization programs as well. Unlike these regional players, however, Turkey essentially has not increased its military expenditure - despite its security challenges. So, what makes Turkey seemingly different?

\section{The financials}

In terms of resources expended on the military, Turkey ranks 15th in the world, slightly below the United Arab Emirates. Turkey also counts among the world's top importers of major weapons, ranking third in the Middle East, after Saudi Arabia and the United Arab Emirates. Compared to Turkey's military expenditure of 4.1 percent of gross domestic product (GDP) in the 1990 s, its military burden in the 2000 s came in at only 

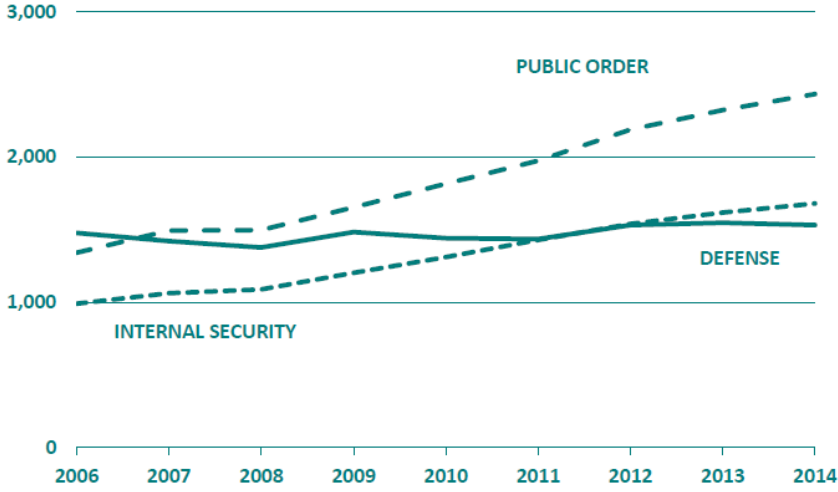

Figure 1: Budget expenditures on internal and external security, 2006-2014 (millions of TRY in constant 1998 prices). Source: http://www.bumko.gov.tr/TR,165/merkezi-yonetim-butce-giderleri -2006-2014.html.

2,000

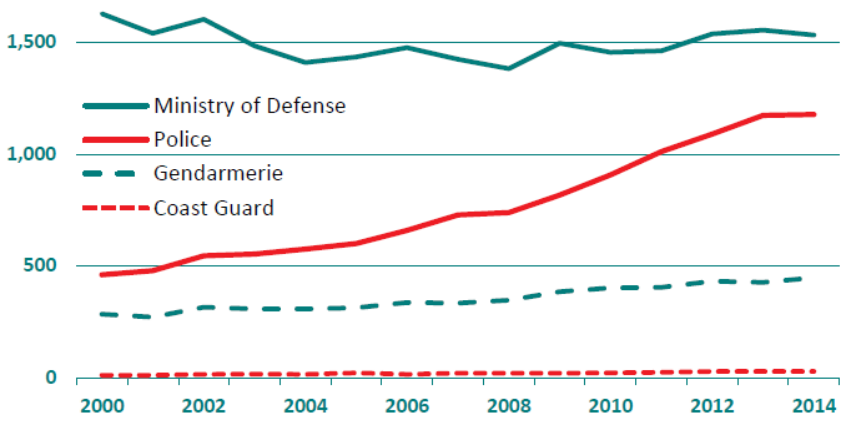

Figure 2: Budgets of security services, 2000-2014 (millions of TRY in constant 1998 prices). Source:

http://www.bumko.gov.tr/TR,5740/2014.html.

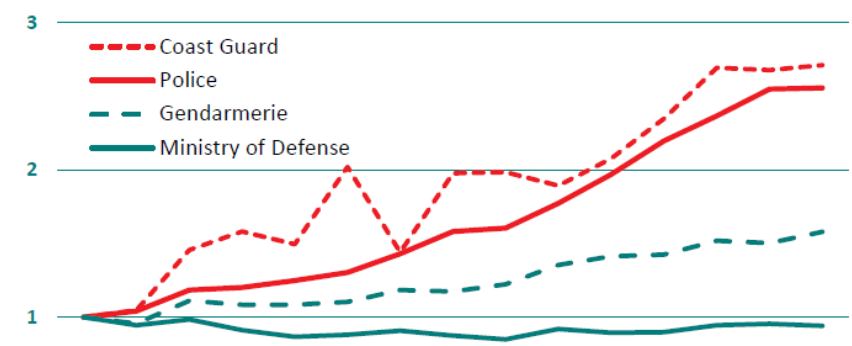
$\begin{array}{llllllll}2000 & 2002 & 2004 & 2006 & 2008 & 2010 & 2012 & 2014\end{array}$

Figure 3: Indexed budgets of security services, 2000-2014 $(2000=1)$. Computed from Figure 2. around $2.2-2.5$ percent. Whatever its military spending growth, it lagged significantly behind the economy's growth rate, hence the lower burden as a percentage of GDP. Still, security expenditure goes beyond allocations to military forces alone, and the emerging dominance of civilian security institutions in Turkey in the 2000s must be accounted for as well. Thus, the first subsection hereunder reflects on Turkish preferences regarding its internal and external security policy design and their effects on resource allocation; the second looks at Turkish security on-budget and off-budget data. ${ }^{21}$

\section{On-budget: Internal security versus external security?}

The functional breakdown of Turkish budget data is available since 2006, in conformance with the European Union's classification. Figure 1 illustrates that spending on public order and safety increased fast - the growth rate for 2006-2014 is 81.4 percent - and especially so since 2008 . Spending on external security, i.e., military expenditure, not only fell below that of public order expenditure but remained sluggish in real terms. The military budget grew by only 3.6 percent. This resulted in a falling share of the military budget in the overall budget (4.7 percent in 2014) and also in GDP (1.2 percent in 2014). Although not wholly unexpected, what is intriguing is the seemingly drastic 69.7 percent growth of internal security spending, now larger than then the country's military budget. ${ }^{22}$

Extending the analysis back to 2000 will serve a broader understanding of the resource allocation patterns for security. Due to lack of data availability, this is possible only if we focus on the agents providing security services. The defense ministry budget and external (military) security link is self-defined. The police force, the gendarmerie, and the coast guard are the other leading agents, expenditures for which are classified almost in their entirety under the internal security rubric of public order and safety, even as the latter two do in fact have dual security mandates. Affiliated with both the interior and defense ministries, the proportion of their internal to external duties is, however, unclear so that the data cannot be adjusted. But in conformity with EU budget norms, and in contrast to the past, the gendarmerie and the coast guard no longer are classified under external security (military) expenditure. ${ }^{23}$

Figure 2 illustrates the relative positions of these security service bodies (in inflation-adjusted terms). As would be expected, the military budget is dominating. What is unexpected is that this budget is stagnant over the whole of the 15 years covered, more so given the preceding discussion in this article on the reoriented perception, role, and nature of Turkey's external security threats. The significant rise in budget allocation for police services is a novel component in Turkey's security fund allocation. As discussed elsewhere,

The Economics of Peace and Security Journal — ISSN 1749-852X — http://www.epsjournal.org.uk (C) EPS Publishing, 2016. All rights reserved. For permissions, email: ManagingEditor@epsjournal.org.uk 

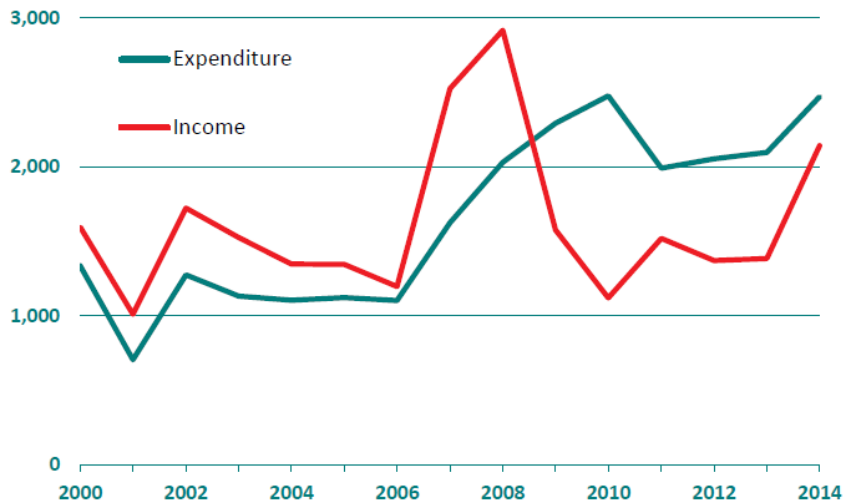

Figure 4: DISF income and expenditure, 2000-2014 (in constant 2009 USD millions). Source: http://www.ssm.gov.tr/anasayfa/ kurumsal/Faaliyet $\% 20$ Raporlar/2013\%20Y\%C4\%B11\%C4\%B1\%2 0Faaliyet\%20Raporu.pdf.

legislative transformations with regard to mandates and accompanying staffing policy are the main underlying factors for this. Note that the gap between the military and police budgets has narrowed significantly from 2000 to 2014. The budget of the gendarmerie ranks third over the same period, while the coast guard budget appears to be relatively small. ${ }^{24}$

Security perceptions and policy priorities might be better reflected by indexation of the relevant budgets. Thus, Figure 3 shows that the military budget has not grown at all. In contrast, while relatively small in magnitude, the budget for the gendarmerie grew by over 50 percent and those of the coast guard and police by more than 150 percent. These increases coincide with the securitization of domestic politics as well as with pressures on border security, especially coastal security in the Mediterranean and Aegean. Mainly, but not solely, due to asylum-seeking triggered by the unrest in Iraq and Syria, the work loads of the near-shore gendarmerie and of the coast guard has increased significantly.

All together, internal and external security spending has had a stable budget share of around 10-12 percent in the 2000s; only its composition has changed. The budget data analysis seems to belie security priorities set by the AKP over the last decade: Even as the spoken emphasis was placed on external security, the practical, financial emphasis favored internal security - at least as far as the on-budget resource allocation is concerned. This invites a closer look, then, at the off-budget resource allocation for security, both internal and external.

\section{Off-budget: Internal security cum external security?}

For the past three decades, Turkish arms modernization has been administered by the Undersecretariat for Defense Industries within the Ministry of National Defense. ${ }^{25}$ The ambition of national arms self-sufficiency mentioned at the start of this article has been realized to some extent-54 percent, in 2015, as reported by the Undersecretariat which monitors domestic and joint arms production and arms imports. As of 2015, of the total value of the contracts, 49 percent is joint production with leading international arms producers, 8 percent is international consortium work, 9 percent is imports and 30 percent is R\&D. Turkey's arms exports (products of domestic and joint ventures) have become more significant over time, now falling between Norway and South Africa. Major buyers are the United Arab Emirates, Saudi Arabia, and Pakistan. The leading arms supplier to Turkey is the United States (58 percent), followed by Spain. The Undersecretariat commands an off-budget facility, called the Defense Industry Support Fund (DISF) which has facilitated time-saving - and public auditing-exempt-off-the-shelf purchasing of armaments for three decades, notwithstanding the promotion of the upgrading of domestic production. ${ }^{26}$

Figure 4 illustrates the scales of off-budget income and expenditure of the Fund, excluding transfers from on-budget resources (especially from the defense and finance ministries). Expenditures have about doubled, in constant dollars, since 2006. (The fluctuation in expenditure is normal, depending on the project stages.) Due to irregular timing of the income streams, the income sources - tax shares, transfers from the budgets of the finance and defense ministries, treasury contributions, and revenues from tangible and intangible assets - might not overlap with expenditures, a fact mentioned only in passing in the reports of the Undersecretariat.

At inception, the function of the DISF fund was limited to the modernization of the army; today, with legislation amended in 2011 and 2014, the facility extends to police and national intelligence as well, implying a consolidation of procurement for internal and external security. Expenditure out of the DISF is estimated to range between 10 and 14 percent of the military budget in the 2000s and at least one-third of military equipment spending is provided by the DISF. (In passing, it should be noted that data transmission and transparency by the DISF has significantly deteriorated over the past decade as compared to the 1990s and early 2000s. The composition of procurement expenditure, e.g., for imports, for internal and external security is undisclosed. $)^{27}$

In a word, the data suggest that Turkey is moving fast toward capacity-building in defense, facilitated mainly by the DISF. Concurrently, funding for internal security is gaining pace. Overall resource allocation is aligned with internal and external security perceptions which are becoming increasingly complementary. 


\section{New alliance partners}

Apart from the drastic growth of internal security spending and capacity building in the defense sector, Turkey also developed ad hoc alliances to break its growing isolation in the region. Although they may not turn out to be sufficiently powerful to create solutions sought by Turkey vis à vis the Syrian conflict, they still are expected to block or slow down developments assumed to harm Turkey's security interests. One dimension of this involves the restoration of ties between Turkey and Israel, damaged after an acrimonious split in 2010 when Israeli commandos raided a Turkish ship carrying supplies to Gaza, killing 10 Turkish activists.

Another dimension includes Turkey's desire to pursue deeper cooperation with Saudi Arabia and Qatar. During President Erdogan's visit to Saudi Arabia in December 2015, a strategic cooperation agreement was signed, covering military, economic, and investment aspects and intended specifically to foster cooperation among 34 Muslim countries against terrorism. Turkey is also building a military base in Qatar which expressed its "full solidarity" with Turkey as it seeks to protect its own borders and preservation of its security and stability. Relatedly, Qatar strongly distanced itself from an Arab League resolution condemning Turkey's bombing of PKK targets in northern Iraq in August 2015. All of these engagements offer certain economic opportunities to Turkey, too. $^{28}$

\section{Conclusion}

The Turkish case tests the proposition that the advantages of economic exchange can pave the way toward conflict resolution regarding territorial problems in the absence of a political climate that favors negotiation and peace building. As regards Greece, Armenia, and the KRG, economic interactions did contribute to the freezing of disagreements but were not sufficient for their resolution.

The case also offers some general lessons. Although the actuality or perception of threat in international relations is often equated to military capabilities, understanding the meaning of threat necessitates an analysis of the central role played by identity. In this regard, the Turkish experience shows that state preferences in favor of economic means as a vehicle of conflict resolution is not just an automatic outcome of a state's adoption of a liberal economic vision. Rather, an application of this vision, as seen in Turkey's effort to transform its border with Syria to a "meaningless" entity, also involves a change in perceptions. The Turkish government's shared sense of identity decreased its threat perception and thus increased its willingness to cooperate, an outcome that is in line with arguments made by social constructivists and social identity theorists. In contrast, the liberal peace hypothesis rests upon the presumption of similarity of regimes and their capacities to build common institutions. Turkey's experience with Syria would seem to undermine the latter hypothesis. Moreover, it is interesting to note that in the Turkish case, change in perceptions of identity and security did not only encourage economic and diplomatic means of resolution but also prepared the ground for Turkey's involvement in Syrian affairs.

While threats to Turkey's security seem to have multiplied in a fashion making internal and external security inseparable, these challenges entwined with budgetary decisions. On-budget components for internal security have grown at a rapid pace and now exceed the external (military) budget. Supplementary evidence comes from the availability of off-budget financing to procure equipment for both military and, since 2011, police and intelligence services. However, without the backing of regional allies, Turkey's own efforts to enhance its security would seem insufficient as the potential break-up of Iraq and Syria would likely produce new territorial disputes, including struggles to define new international borders.

Notes

The authors thank Jurgen Brauer for critical comments which helped to improve the text significantly.

1. Territory triggers crisis: Huth and Allee (2002) find that 348 territorial conflicts from 1919 to 1995 are linked to 374 militarized disputes and 40 interstate wars. Mobilize domestic support: Agnew and Corbridge (1995); Kliot and Newman (2000). Liberal peace scholars: Rosecrance (1999).

\section{Ex-ambassador: Elekdag (1994).}

3. New foreign policy approach: Dagi (2009). Energy corridor: Barkey (2011).

4. New vocabulary and terms: Aras (2009). Soft-power assets: Oguzlu (2007). Interdependence and mediation: Altunışık (2008); Ayman (2011). Annan Plan: Oktay and Kinacioglu (2007). Greece: From 2000 to 2013, more than 100 bilateral agreements were signed and led to flourishing trade between the two countries. Reciprocal foreign direct investments of Greek and Turkish companies, bilateral tourism, and cooperation in cultural and scientific fields all increased, and railroads connecting the two countries have been improved. In addition, a Council of Strategic Cooperation was established in which both prime ministers meet annually and joint ventures were undertaken for the construction of the Interconnector Turkey-Greece-Italy (ITGI) natural gas pipeline. Growing bilateral trade: Onis and Yilmaz (2008). Armenia: Goshgarian (2005).

5. Disappointed: Oguzlu (2008). Unresolved: The only exception concerned the adoption of confidence building measures, since 2000, aimed at reducing tension emanating 
from conflicts over Cyprus and the Aegean Sea. Talks took place under the auspices of NATO and between the political directors of the respective foreign ministries. However, the measures agreed to so far are largely targeted at crisis management, not resolution of the issues at hand. Cyprus offshore fields: Andoura and Koranyi (2014).

6. Ozkan (2010).

7. Quote: Kiniklioglu (2009).

8. Hydrocarbon-rich countries: Biresselioglu (2011).

9. Economic relations and trade: In 2002, the European Union's share of total exports from Turkey was 56.5 percent. This figure fell to 46.3 percent in 2010. Africa's share, including some Muslim North African countries, was 4.7 percent in 2002, and it rose to 8.2 percent in 2010. Also, Middle Eastern countries' share rose from 9.6 percent in 2002 to 20.3 percent. According to Turkish Statistics Institute data, the countries that increased the amount of goods purchased from Turkey in 2010 compared to 2008 included Egypt (83.6 percent), Libya (67.5 percent), Iraq (30.8 percent), Syria (27.8 percent), Algeria (10.4 percent), Senegal (6 percent), and Pakistan (5.2 percent). Trading state: Kirisci (2009).

10. In 1939, the French government ceded Syria's Hatay (Alexandretta) province to Turkey, in essence an annexation, in order to assure Ankara's signing of a nonaggression pact and hoping that Turkey would join England and France against Nazi Germany in the second world war. This met with heavy protests in Syria, then still struggling for independence from France. Although the French decision was accepted in practice as a necessary concession to secure Syrian independence, afterward the country staunchly refused to recognize the border that now separated Hatay from Syria. Official Syrian maps continued to include Hatay as part of the country's national territory. See Tur (2016, pp. 112-118).

11. Turkish-Syrian free trade agreement: Akinci (2004). Also see Syria (2009), Turkiye-Suriye (2010), and Enginsoy (2010).

12. Dombey (2011).

13. Quote: AKP (2011).

14. For the challenges of the refugee crisis see Kirisci (2014, pp. 18-38). Greek accusation: See DW (2016).

15. New approach to border security: Yesiltas (2013). Border personnel: TDN (2015).

16. For an interview with Turkish Deputy Prime Minister Numan Kurtulmus on this subject see DS (2016).

17. For a listing of recent PKK attacks in Turkey, see Guardian (2016). For a similar list of ISIS attacks, see Yourish, et al. (2016).

18. Hurriyet (2015).

19. Missile defense capabilities: Egeli (2013).

20. Russian missiles in Armenia: Kasapoglu (2014).
21. Military resources: SIPRI (2015, p. 352). The military expenditure data referred to here includes the military budget and other resources allocated to the military (SIPRI, 2015, p. 400). In the Turkish case, this number exceeds the national military budget by $30-40$ percent in the 2000 s. Arms imports: SIPRI (2015, pp. 417-418, 420). Military burden: SIPRI (2015, p. 394). Civilian security institutions: Gunluk-Senesen and Kirik (2016).

22. Public order and safety expenditure comprises the following categories: Police services, fire protection services, law courts, prisons, R\&D related to public order and safety, and expenditure not elsewhere classified. For defense, the categories are: Military and civil defense, foreign military aid, and $R \& D$ related to defense. See EC (undated). Budget data, as used in the main text, comes from Turkey's Ministry of Finance. The GDP deflator, derived from TurkStat, is used to convert the data into constant prices.

23. Inseparable: Gunluk-Senesen and Kirik (2016). Although there are additional items in the public order and safety category, raising mostly unexplored issues with regard to their contribution to overall safety and security, we restrict our analysis here to the items listed in the main text. In contrast to the past: See, e.g., Gunluk-Senesen (2002).

24. Elsewhere: See Gunluk-Senesen and Kirik (2016).

25. For more information on the activities of the Undersecratariat, see http://www.ssm.gov.tr/home/Sayfalar/ default.aspx. Financial data is compiled from various annual reports of the Secretariat, e.g. Savunma Sanayii Mustesarligi Faaliyet Raporu (2015). There are irregularities, especially very recently, in bout currency units, USD and TRY. We stick to the available series in USD, published earlier. See http:/www.ssm.gov.tr/anasayfa/kurumsal/Faaliyet\%20Rapor lar/2015\%20Y\%C4\%B11\%C4\%B1\%20Faaliyet\%20Raporu. pdf [accessed 20 March 2016].

26. Major buyers: SIPRI (2015, p. 407). Major suppliers: SIPRI (2015, p. 420).

27. At inception: Gunluk-Senesen (1993). Consolidation: Gunluk-Senesen and Kirik (2016). DISF: Kirik and Gunluk-Senesen (2012).

28. Turkey-Israel: Reuters (2016). Turkey-Saudi Arabia: Barchard (2016). Turkey-Qatar: Cafiero and Wagner (2015).

\section{References}

Agnew, J.A. and S. Corbridge. 1995. Mastering Space: Hegemony, Territory and International Political Economy. New York: Routledge.

http://dx.doi.org/10.4324/9780203422380

Akinci, B. 2004. "Newly Found Friendship between Turkey and Syria." Middle East Online. Vol. 23 (December). www.middle-east-online.com/english/?id=12236 [accessed 13 April 2016].

[AKP] 2011. "Syria is Our Domestic Problem." 7 August. https://www.akparti.org.tr/english/haberler/syria-is-our-d omestic-problem/11535\#1 
Altunisik, M. 2008. "The Possibilities and Limits of Turkey’s Soft Power in the Middle East." Insight Turkey. Vol. 10, No. 2, pp. 41-54.

Andoura S. and D. Korayni, eds. 2014. Energy in the Eastern Mediterranean: Promise or Peril? Joint Report by the Egmont Institute and the Atlantic Council. Academia Press. May. http://www.egmontinstitute.be/wp-content/uploads/ 2014/05/ep65.pdf [accessed 13 April 2016].

Aras, B. 2009. "The Davutoglu Era in Turkish Foreign Policy." SETA Policy Brief. No. 32 (May). http://arsiv.setav.org/ups/dosya/20875.pdf [accessed 13 April 2016].

Ayman, G. 2011. "An Analysis of Turkish Mediation in the Middle East in an Era of Turmoil." D1ş Politika-Foreign Policy. 40 th Anniversary Issue. Vol. 37, Nos. 3-4, pp. 7-25.

Bachard, D. 2016. "With US no Longer Tusted, Turkey and Saudi Forge New Alliance.” Middle East Eye. 13 April. http://www.middleeasteye.net/columns/regional-tensions -push-saudi-arabia-and-turkey-towards-closer-ties-23636 9218\#sthash.YZmylhtu.dpuf.

Barkey, H. 2011. "Turkey and Iraq: The Making of a Partnership." Turkish Studies. Special Issue: Turkey and the Middle East. Vol. 12, No. 4, pp. 663-674.

Biresselioglu, M.E. 2011. “Turkey's Transforming Relations with the Arab World: The Impact of Recent Turkish High-Level Visits to the Gulf Region." http://www.balkanalysis.com/turkey/2011/01/27/turkey\% E2\%80\%99s-transforming-relations-with-the-arab-world -the-impact-of-recent-turkish-high-level-visits-to-the-gulf -region/ [accessed 13 April 2016].

Cafiero, G. and D. Wagner. 2015. "Turkey and Qatar: Close Allies, Sharing a Doomed Syria Policy." The National Interest. 9 November. http://nationalinterest.org/feature/ feature/turkey-qatar-close-allies-sharing-doomed-syria-p olicy-14283.

Dagi, I. 2009. "The Liberal Turn in Turkish Foreign Policy." Today's Zaman. (23 February). [Source no longer accessible as the newspaper's archive was banned by the government.]

Dombey, D. 2011. "Ahmet Davutoglu: Renewed Confidence is on Display." Financial Times. 21 November. http://www.ft.com/intl/cms/s/0/712dd55a-09fe-11e1-8d4 6-00144feabdc0.html\#axzz461QNdJN6.

[DS] "Turkey Rejects plan to Partition Syria: Deputy PM." Da ily Sabah. $6 \quad \mathrm{March} \quad 2016$. http://www.dailysabah.com/politics/2016/03/06/turkey-re jects-plan-to-partition-syria-deputy-pm [accessed 13 April 2016].

[DW] "Greek President Accuses Turkish Authorities of Smuggling Refugees.” Deutsche Welle. 18 January 2016. http://www.dw.com/en/greek-president-accuses-turkish-a uthorities-of-smuggling-refugees/a-18988011 [accessed 13 April 2016].

[EC]Undated.http://ec.europa.eu/eurostat/statistics-explained /index.php/Glossary:Classification_of_the_functions_of_
government_(COFOG) [accessed 20 March 2016].

Egeli, S. 2013. Füze Tehdidi ve NATO Füze Kalkani. Istanbul: Bilgi Üniversitesi Yayinlari.

Elekdag, S. 1994. "2.5 War Strategy." Milliyet. 27 November. http://sam.gov.tr/2-12-war-strategy-4/

Enginsoy, U. 2010. "Turkey to Set Up Trade Zone with Syria, Lebanon, Jordan.” Hurriyet Daily News. 11 July 2010. http://www.hurriyetdailynews.com/default.aspx?pageid= 438\&n=turkey-to-set-up-trade-zone-with-syria-lebanon-j ordan-2010-11-07 [accessed 13 April 2016].

Goshgarian, R. 2005. "Breaking the Stalemate: Turkish-Armenian Relations in the 21st Century." Turkish Policy Quarterly. Vol. 4, No. 4, pp. 4-5.

[Guardian] "Turkey Attacks: A Timeline." The Guardian. 18 February 2016. http://www.theguardian.com/world/2016/ feb/18/turkey-attacks-a-timeline [accessed 3 April 2016].

Gunluk-Senesen, G. 1993. "Turkey: The Arms Industry Modernization Programme," pp. 251-267 (chapter 13) in H. Wulf, ed. Arms Industry Limited. Oxford, UK: Oxford University Press.

Gunluk-Senesen, G. 2002. "Budgetary Trade-offs of Security Expenditures in Turkey." Defence and Peace Economics. Vol. 13, No. 5, pp. 385-403. http://dx.doi.org/10.1080/10242690213509

Gunluk-Senesen, G. and H. Kirik. 2016. "The AKP Era: Democratization or Resecuritization? An Assessment of the Institutional and Budgetary Reflections." Research and Policy on Turkey. Vol. 1, No. 1, pp. 75-87. http://dx.doi.org/10.1080/23760818.2015.1099783

[Hurriyet] 2010. "Turkiye-Suriye ortak sinir kapisinin temeli 1-2 ay icinde atilacak." Hurriyet. 13 June 2010. http://www.hurriyet.com.tr/turkiye-suriye-ortak-sinir-kap isinin-temeli-1-2-ay-icinde-atilacak-15007780 [accessed 13 April 2016].

[Hurriyet] 2015. “Org. Özel Savunma ve Havacıllk Dergisi’ne konuştu." Hurriyet. 25 March 2015. http://www.hurriyet.com.tr/org-ozel-savunma-ve-havacili k-dergisi-ne-konustu-28549591 [accessed 13 April 2016].

Huth, P.K. and T.L. Allee. 2002. The Democratic Peace and Territorial Conflict in the Twentieth Century. Cambridge, UK: Cambridge University Press.

Kasapoğlu, C. 2014. "Uzun Menzilli Bölge Hava ve Füze Savunma Sistemi Projesi: Ankara'nın Tercihlerini A n 1 a m a k." EDAM. ( D e c e m b e r). http://www.edam.org.tr/tr/File?id=2163 [accessed 3 April 2016].

Kiniklioglu, S. 2009. "Neo-Ottoman' Turkey?" Project Syndicate. https://www.project-syndicate.org/commentary/ -neo-ottoman--turkey?barrier=true [accessed 13 April 2016].

Kirik, H. and G. Gunluk-Senesen. 2012. "Conflict or Concession? Political and Economic Aspects of the Civil-military Relations in Turkey in the 2000s." Paper presented at the Sixteenth Annual International Conference on Economics and Security, 21-22 June 2012, Cairo.

Kirişci, K. 2009. "The Transformation of Turkish Foreign 
Policy: The Rise of the Trading State." New Perspectives on Turkey. No. 40, pp. 29-57. http://dx.doi.org/10.1017/S0896634600005203

Kirisci, K. 2014. “Syrian Refugees and Turkey's Challenges: Going Beyond Hospitality." The Brookings Institution. http://www.brookings.edu/ /media/research/files/reports/ 2014/05/12-turkey-syrian-refugees-kirisci/syrian-refugee s-and-turkeys-challenges-may-14-2014.pdf [accessed 13 April 2016].

Kliot, N and D. Newman. 2000. Geopolitics at the End of the Twentieth Century. London: Frank Cass.

Kutlay, M. 2014. "Türkiye-Ortadoğu Ticari İliskilerinin Politik Ekonomisi.” Ortadogu Analiz, ORSAM. Vol. 6, No. 62, pp. 58-59. http://www.orsam.org.tr/tr/trUploads/Yazilar/ Dosyalar/201457_15mustafakutlay.pdf [accessed 13 April 2016].

Oguzlu, T. 2007. "Soft Power in Turkish Foreign Policy." Australian Journal of International Affairs. Vol. 61, No. 1, pp. 81-97.

http://dx.doi.org/10.1080/10357710601142518

Oguzlu, T. 2008. “Middle Easternization of Turkey's Foreign Policy: Does Turkey Dissociate from the West?" Turkish Studies. Vol. 9, No. 1, pp. 3-20. http://dx.doi.org/10.1080/14683840701813960

Oktay, M., and E. Kinacioglu. 2007. “The Domestic Dynamics of Turkey's Cyprus Policy: Implications for Turkey's Accession to the European Union." Turkish Studies. Vol. 7 No. 2, pp. 261-273.

Onis, Z., and Ş. Yilmaz. 2008. "Greek-Turkish Rapprochement: Rhetoric or Reality?" Political Science Quarterly. Vol. 123, No. 1, pp. 123-149. http://dx.doi.org/10.1002/j.1538-165X.2008.tb00619.x

Ozkan, G. 2010. "Turkish-Armenian Protocols: Any Hope Left?" Hurriyet Daily News. 30 April. http:/www.hurriyetdailynews.com/turkish-armenian-prot ocols-any-hope-left.aspx?pageID $=438 \& n=$ turkish-armeni an-protocols-any-hope-left-2010-04-30 [accessed 13 April 2016].

[Reuters] 2016. "Turkey, Israel make Progress on Deal to Restore Ties: Turkish Ministry." 8 April. http://www.reuters.com/article/us-turkey-israel idUSKCN0X509W

Rosecrance, R. 1999. The Rise of the Virtual State. New York: Basic Books.

[SIPRI] Stockholm International Peace Research Institute. 2015. SIPRI Yearbook 2015 Armaments, Disarmament and International Security. Oxford, UK: Oxford University Press.

[Syria] Government of Syria. 2009. "The Association Agreement Establishing a Free Trade Area between the Syrian Arab Republic and the Republic of Turkey." http://investmentpolicyhub.unctad.org/Download/Treaty File/2702 [accessed 13 April 2016].

[TDN] "Turkey to Fly Surveillance Balloons, Build New Fence and Moat for Border Security." Turkish Daily News. 23 July 2015. http://www.hurriyetdailynews.com/turkey -to-fly-surveillance-balloons-build-new-fence-and-moat-f or-border-security.aspx? pageID $=238 \& n I D=85810 \& N e w$ $\mathrm{sCatID}=510$ [accessed 13 April 2016].

Tur, O. 2016. Turkey-Syria Relations: Between Enmity and Amity. London: Routledge.

Yesiltas, M. 2013. Ic Savasa Komsu Olmak: Türkiye'nin Suriye $\mathrm{S}$ i $n$ n $\mathrm{i}$ r Guvenligi Siyaseti, SETAV. http://setav.org/tr/ic-savasa-komsu-olmak-turkiyenin-suri ye-sinir-guvenligi-siyaseti/analiz/27026 [accessed 13 April 2016].

Yourish, K., T. Wallace, D. Watkins, and T. Giratikanon. 2016. "Brussels Is Latest Target in Islamic State's Assault on West." The New York Times. 25 March 2016.http://www.nytimes.com/interactive/2016/03/25/wo $\mathrm{rld} / \mathrm{map}$-isis-attacks-around-the-world.html [accessed 13 April 2016]. 